\title{
Me and Art History - The Contribution of Art History Studies to Students' Identity Work
}

\author{
Jari Martikainen \\ University of Eastern Finland \\ Kuopio, Finland \\ Anneli Hujala and Sanna Laulainen \\ University of Eastern Finland \\ Kuopio, Finland
}

\begin{abstract}
This research explores the relationship between art history studies and identity, as inspired by students' initiative to discuss matters related to identity during art history lessons. The research has two research questions: 1) Do students find art history meaningful in terms of identity? and 2) What kinds of thoughts and ideas of identity are generated when studying art history? Twenty-four students of visual arts and photography at an upper-secondary vocational college in Finland took part in the research and produced research material by reflecting on topics related to identity in writing. The data were analyzed using content analysis. The results show that all the students found art history meaningful in terms of identity work and could identify changes in their self-conception as well as the conception of the world around them. Art history studies provided the students with a novel insight into themselves, as well as into societies and cultures, broadening their world-view and fostering their identities as art students and future artists.
\end{abstract}

Keywords: identity; art history; social constructionism.

\section{Introduction}

"The self today is for everyone a reflexive project - a more or less continuous interrogation of past, present and future." (Giddens, 1992, p. 30)

The above quotation from Anthony Giddens (1992) characterizes identity work as a constant process of reorientation in which people update their understanding of themselves using time-related experiences and aspirations as coordinates. The attempt to understand who we are and where we come from is 
regarded as a fundamental human motivation as well as a life-long process (Bamberg, 2011; Chere-Masopha, 2018; Riechman, 2016). The concepts of self and identity are popular research topics in many fields of science, and are often related, on one hand, to the increased individualism typical of our present culture, and on the other hand, to drastic changes and diversity in contemporary societies (Bamberg, De Fina \& Schiffrin, 2011; Chere-Masopha, 2018; Rautio \& Saastamoinen, 2006; Yeo et al., 2019). The need to reflect on one's life has intensified in contemporary times, which is often related to the inability of eroded and rapidly changed cultural traditions and social structures to provide people with explanations concerning their identities (Larsen \& Patterson, 2018; Saastamoinen, 2006a, 2006b). Identity work as a "reflexive process" (Giddens, 1992, p. 30) attempting to construct coherence and continuity for individual experience of life has become more and more important (Adams, 2003; Gardner \& Garr-Schultz, 2018; Laulainen \& Hujala, 2016; McLean, 2008; Riechman, 2016; Waters \& Fivush, 2015), and people are expected to bear responsibility for it themselves (Saastamoinen, 2006a, 2006b).

Identity has become a current topic in art history, as well. During the second half of the $20^{\text {th }}$ century, the conception of art history as an objective field of science based on connoisseurship gave way to the conception of art history as constructed from a variety of approaches, positions, and interests (Mansfield, 2007; Miller et al., 2018; Pooke \& Newall, 2008). The image of art history as a coherent field of study was broken and attention was paid to the heterogeneity of the discipline (Krieger, 2008; Pooke \& Newall, 2008; Van Mechelen \& Zijlmans, 2012). The interest in the politics of vision, artistic perception, and the power of images broadened the scope of the discipline toward visual culture studies, and art history became associated with the construction of cultural identities (Harris, 2001; Kraynak, 2008; Zijlmans, 2008).

As the perception of artworks and the experiences generated by them became accepted as an approach to art historical research, questions of identity became actual, in terms of both art historians' positions of making art history and perceivers' positions of interpreting works of art (Ankersmit, 2003; Martikainen, 2011; Pooke \& Newall, 2008). Why do art historians approach art historical topics and works of art in the way they do? What is the contribution of the perception of artworks by different audiences? Such questions related art history to the problems of identity, since, on one hand, our cultural, social, and personal backgrounds and positions influence the ways in which we interpret artworks, and on the other hand, by providing a frame of reflection, artworks may broaden our conceptions of ourselves, other people, and the world at large (Martikainen, 2017a; Pooke \& Newall, 2008). In addition, "world art history" at the end of the $20^{\text {th }}$ century and the beginning of the $21^{\text {st }}$ century paid attention to approaches and concepts other than those of Western of art history, diversifying the scope of a previously predominantly Western discipline (van Damme, 2008; Zijlmans, 2008) and activating the questions of identity in terms of cultural frames of making art history (Martikainen, 2011; Zijlmans, 2008). 
In the context of this research, methods of observing works of art and making art history-related visual products, such as drawings, paintings, woodcuts and sculptures, were included in the art history studies to promote both reflection on diverse art historical topics and self-reflection. Prior research on art history pedagogy and art education (Blocker, 2004; Ericson, 2004; Martikainen, 2017b; Sabol, 2000) has found that these methods may encourage students to use their own lived experiences as a resource in making sense of artworks and other art historical topics, increasing self-reflection. As a result, art history may emerge as a dialogue between students' lived experiences, on one hand, and people, ideas, and phenomena represented by artworks from various cultures and periods of time, on the other hand (Martikainen, 2017a). In picture-based study arrangements, works of art may function as cultural mirrors (Martikainen, 2011) through which students reflect not only on the matters and topics depicted in the works of art but also on themselves, their own thoughts, and the experiences related to them.

The research at hand arose from discussions with students during an art history course (The first author of this article was their art history teacher.) When reflecting on past and present artworks, students frequently mentioned themes connected with identity. For example, they noticed and assumed that people's different backgrounds (e.g., age, gender, culture) contribute to the interpretation of artworks, or that they had learned new aspects of themselves when studying art history. Some students also felt they could identify with artists from past periods of time when exploring their artworks through making pictures. In order to promote these student-centered initiatives, the teacher of the course prepared two lessons in which students could reflect on identity in relation to art history. Since the concept of identity is regarded as offering a tool for reflecting the relation between personal and cultural experiences (Saastamoinen, 2006b), the initiative of the students was highly relevant in the frame of contemporary art history.

This research examines the relation between art history studies and student identity. At first, past and present conceptions of identity are presented and discussed in the literature review. Thereafter, the theoretical basis of the research - namely social constructionism - is explicated and related to the concept of identity. The students' written reflections on the relationship between art history and identity form the data of this research, which were analyzed using content analysis. The results are discussed with reference to prior research on identity. Finally, some concluding notions related to the relationship between identity and studying and teaching art history, as well as future orientations, are brought up.

\section{Purpose of the research}

The purpose of this research is to explore the relationship between art history studies and students' identity work. The research has two research questions: 1) do students regard art history as meaningful in terms of identity, and 2) what 
kinds of ideas and experiences of identity are generated among students when studying art history.

\section{Literature review}

Different historical periods of time and different cultures, as well as different scientific traditions, have understood identity in different ways (Bamberg, 2011; LaPointe, 2011). For this reason, it is not our intention to give any encompassing definitions of identity in this research but rather to shed light on some central approaches to identity in Western cultures. In the psychological sciences, the concept of man has been studied using the concepts of self, identity, and personality (Oyserman, Elmore \& Smith, 2012; Rautio, 2006). Even though these concepts are, in many cases, used more or less synonymously (Bamberg et al., 2011; Saastamoinen, 2006b), 'self' is often regarded as more individualistic, whereas 'identity' is considered as bridging individualistic and social and cultural spheres, and is therefore used predominantly in sociology, social psychology, and culture studies (Bamberg, 2011; Rautio, 2006). The concept of identity is usually divided into personal and social identities. While personal identity refers to the sense of continuity and coherence in an individual's life experience, social identity refers to either an individual's identification with social groups or consistency in terms of acting in various social roles (Laulainen \& Hujala, 2016; Onorato \& Turner, 2004; Riechman, 2016; Saastamoinen, 2006b). In this research, identity is broadly understood as people's conception of "who they were, are, and desire to become" (Brown, 2015, p. 20), including their relation to other people and to their social and cultural contexts (see also Saastamoinen, 2006b). Consequently, identity work is understood as a process in which people narrate and construct their identities using their lived experiences, relations to other people, and cultural and social knowledge as resources (Beech, MacIntosh \& McInnes, 2008; Brown, 2015; Leath et al., 2019).

The origin of studies discussing identity-related issues can be traced back to the work of the ancient Greek philosophers, such as Plato and Aristotle (Rautio, 2006). However, a more systematic theorizing about identity originated with the Stoic philosophers in the European Middle Ages, according to whom, people were capable of receiving impressions from the outer world and other people, and of using these as information about their own selves (Nawar, 2017; Rautio, 2006). The idea of using impressions gained "outside the individual" in forming self-conception is later echoed in existentialist and pragmatist conceptions of identity in the 19th and 20th centuries (Mead, 2015; Waterman, 2014).

In the 17th century, René Descartes laid the foundation for the dualistic tradition according to which human beings are composed of an immaterial mind and a material body, known as Cartesian dualism (Gaudemard, 2018). Even though these components were understood as influencing each other and forming the whole, Descartes prioritized the mind and rational consciousness (Gaudemard, 2018; Hamilton \& Hamilton, 2015). In the 18 th century, David Hume assumed that all human thought is based on sensory experiences of either the internal states of human beings or the world around them. Hume criticized Descartes's 
conception of self and claimed that people cannot know their own selves but only a stock of impressions provided by senses, feelings, and thoughts (Rautio, 2006). In the $18^{\text {th }}$ century, Immanuel Kant presented his conception of the transcendental self, according to which the self is the agent of experience that organizes perceptions of the outer world from sensory chaos to structured order (Dyck, 2006; Rautio, 2006; Saji, 2011).

In the essentialist tradition, identity is regarded as an individual's internal, mental construct (Gosine, 2002; LaPointe, 2011). Reflecting the conceptions of humanism and rationalism of the $16^{\text {th }}$ and $17^{\text {th }}$ centuries, as well as the ideals of the Enlightenment, the essentialist tradition considers identity as a cognitive self, guided by reason (LaPointe, 2011; Ryazanov \& Christenfelt, 2017). In this approach, identity is regarded as an innate, stable, and unitary inner core of an individual, waiting to be discovered (Benwell \& Stokoe, 2006; Kuusela, 2006; LaPointe, 2011). A different perspective is provided by the existentialist tradition, according to which identity is not something ascribed to human beings prior to experience (Bilsker, 1992; Fuller, 2018). In contrast, identity is formed through existence by experiencing the world and is constructed by people free to choose who they become, guided by their goals, values, and beliefs (Waterman, 2014; Fuller, 2018).

At the beginning of the $20^{\text {th }}$ century, a different conception of self began to emerge in the fields of sociology and social psychology (LaPointe, 2011). William James's work is often seen as the milestone marking the shift from the philosophy of the self to the psychology of the self (Kuusela, 2006; Pistioli, 2018; Rautio, 2006). James regarded the self as being composed of material, social, and spiritual selves. While the material self includes the body, as well as people and objects meaningful to the individual, the social self manifests itself as multiple selves adjusted to affiliated people (Pistioli, 2018). The spiritual self, in turn, encompasses worldviews, religions, and interpretations of oneself. A central ability of the spiritual self is to observe and reflect on one's own thoughts and produce interpretations of them (Rautio, 2006; Zhao, 2014).

A significant change in James's conception of self was that it was no longer regarded as an individual, autonomous, and static entity, but rather a dynamic construct consisting of multiple layers formed in a historical and cultural context in social interaction (LaPointe, 2011; Rautio, 2006). Starting with the American pragmatists such as Mead, and further developed in symbolic interactibonism, participation in everyday life and social interaction was considered to be the seedbed of the self (LaPointe, 2011; Mead, 2105). Mead's (2015) notion that the self can develop and exist only in relation to other selves, and is a product of social relations with other people, laid the foundation for later theories of social identity (Rautio, 2006).

Deviating from psychological views on identity, in which it was seen as the process of individuation, the social identity theories shifted the focus from individual cognitive mechanisms to the social origins of identity formation (LaPointe, 2011). In social identity theories, the processes of self-categorization 
and social comparison form the core of identity work (Stets \& Burke, 2000). In these theories, the self is regarded as reflexive, being able to take itself as the object and categorize itself in relation to other social categories (Kendell, 2009; Stets \& Burke, 2000). Thus, an individual person is considered to have multiple identities associated with various groups they affiliate with, as well as the roles they have (Tajfel \&Turner, 2004; see also Stets \& Burke, 2000). Through social comparison, people similar to the self are classified as ingroup, and people different to the self as outgroup (Cameron, 2004; Tajfel \& Turner, 2004). However, these identities are regarded as relatively stable (LaPointe, 2011).

In the second half of the $20^{\text {th }}$ century, feminist, poststructuralist, postmodern, and social constructionist approaches regarded identities as socially and culturally constructed clusters in response to various historical and social situations (LaPointe, 2011; Parfit, 2017). Identities became intertwined with discursive, symbolic practices and were understood as being constructed and performed through them (Bamberg et al., 2011; Leath et al., 2019). Simultaneously, critical approaches to identity brought up questions of power, aiming to reveal power positions and persuasive mechanisms embedded in discursive practices (Bamberg et al., 2011; LaPointe, 2011; Leath et al., 2019). By taking part in discursive practices, people not only construct their identities, but simultaneously also social realities, as stated by representants of social constructionism (Bamberg et al., 2011; Burr, 2015; Laulainen \& Hujala, 2016; Ruelle \& Peverelli, 2017; Saastamoinen, 2006b). In contemporary times, identity work in terms of constructing identities associated with various contexts, as well as in terms of narrating continuity between various contextual identities, has become increasingly important (Beech et al., 2008; Brown, 2015; Leath et al., 2019).

\section{Theory}

Theoretically, this research draws on social constructionism, according to which people construct their social reality through their discursive practices (Berger \& Luckmann, 1991; Burr, 2015) Based on their knowledge, perceptions and experiences, people fabricate different versions of knowledge and social reality in their social interaction (Burr, 2015). By taking part in discursive practices, people not only construct their social realities, but simultaneously also their identities, as stated by representants of social constructionism (Bamberg et al., 2011; Burr, 2015; Ruelle \& Peverelli, 2017; Saastamoinen, 2006b). Followingly, this research regards identity as a process in which individuals construct and narrate the conception of themselves in relation to their prior knowledge and experiences, to their future aspirations, to other people, and to their social and cultural contexts. Thus, the approach draws on social constructionism, assuming that studying art history may provide students with experiences and knowledge that they can use as resources in constructing their identities. 


\section{Methodology}

\subsection{Participants}

A total of twenty-four students (18 females and 6 males) majoring in visual arts and photography at an upper-secondary vocational college in Finland participated in the case study. All the participants were first-year students and their age varied between 16 and 25 years (see Table 1). The participants were students in two art history courses taught by the first author of this article. The distribution of students in terms of gender and age is typical for study groups in this particular vocational college as well as in vocational colleges in Finland in general. None of the students had studied art history before.

Table 1. Distribution of participants.

\begin{tabular}{|l|l|}
\hline Participant information & Number of Students \\
\hline total number of students & 24 \\
\hline female & 18 \\
\hline male & 6 \\
\hline age: $16-20$ & 19 \\
\hline age: $21-25$ & 5 \\
\hline majoring in visual arts & 14 \\
\hline majoring in photography & 10 \\
\hline
\end{tabular}

\subsection{Study design and procedure}

The study at hand is a qualitative case study examining students' conceptions of the relationship between art history studies and identity. The data were collected by asking the students to answer six questions posed to them in writing. Three of the questions were close-ended questions (which students could answer 'yes' or 'no'), and, the remaining three questions were open questions inviting the students to write about their thoughts and ideas in their own words. Thus, the research tool combined features of a questionnaire and a more qualitative form of writing. The answers to the close-ended questions were quantified and the answers to the open questions were analyzed inductively using content analysis. In order to increase the transparency and reliability of the inductive content analysis, the themes identified in the data were quantified as well. Quantification made it possible to indicate which themes emerged most frequently in the data. However, the themes as well as the thoughts and experiences related to them form the main findings of this research. Since this is a small-scale case study with participants from one upper-secondary vocational college in Finland, the results are not statistically generalizable.

Because the students raised issues related to identity during art history lessons, the teacher decided to follow this student-centered initiative and prepared two lessons in which students had a chance to reflect on identity and the relation between identity and art history studies. In order to find out how students understand identity, the concept of 'identity' was not discussed in detail in advance, but only characterized broadly as people's conceptions of who they are (see Saastamoinen, 2006b). During the lessons, students had a chance to reflect 
on identity in writing. The written reflections served primarily pedagogic purposes (e.g., reflection on the relevance of art history studies, development of metacognitive skills and multicultural sensitivity) and only secondarily research purposes. The students were informed about the research in advance and they could freely decide whether or not to give permission for their answers to be used as research data. All the students gave permission for their answers to be used for the research.

The students were led to reflect on identity within the frame of art history in two separate lessons. In the first lesson, the students were simply asked to consider whether they regarded art history as meaningful in terms of identity, and if yes, how art history can contribute to identity. Thirty-minutes were reserved for the assignment. The students were asked two questions:

- Is art history meaningful in terms of identity?

- How can art history contribute to identity?

This first stage of the research was designed to serve as an affordance for students to consider the topic in general without relating it to themselves. Students' answers revealed that the two most frequently mentioned links between art history and identity were that art history may contribute to selfconception and conception of the world. These two aspects were addressed in another lesson two weeks later, when the students were asked to reflect on the contribution of art history studies to their own self-conception and the conception of the world. Forty-five minutes were reserved for the assignment. Consequently, the students were asked four additional questions:

- Has your self-conception changed during art history studies?

- If you feel that your self-conception has changed, please specify how?

- Has your conception or understanding of the world changed during art history studies?

- If, yes, please specify how studying art history has changed your conception or understanding of the world?

\subsection{Data and data analysis}

In total, the data consisted of 31 hand-written pages where students wrote about their thoughts and experiences about the relationship between art history studies and identity. The research was conducted using qualitative methods. Since the research aimed to gain an insight into how students understand identity and how they experience the role of art history studies in terms of identity, it was important that the students had the chance to discuss their thoughts and experiences in their own words (Daher et al., 2017; Knapik, 2006). This kind of design was also thought to better serve the pedagogic aims, which were namely self-reflection and development of metacognitive skills and multicultural sensitivity.

The data were analyzed using content analysis. The answers were quantified and categorized as is typical for content analysis (Krippendorff, 2013; Moser \& 
Korstens, 2018). The quantification concretized the number of students who mentioned a particular identity-related theme. The purpose of this type of quantification is to increase the transparency of the analysis and provide an overview of the "tendencies" in the data (see Neale, Miller \& West, 2014), such as how many students experienced art history as meaningful in terms of identity or if some aspects of identity were thematized more frequently than others. However, the analysis focused primarily on detecting the themes that students experienced as meaningful in terms of identity related to art history studies (see Moser \& Korstens, 2018). Thus, the analysis was conducted inductively, paying careful attention to the themes brought up by the students themselves (see Daher et al., 2017; Moser \& Korstens, 2018). In addition, the themes detected in the first part of the written reflection formed the basis for the questions in the second part of the written reflection.

In the results section, the findings from the first written reflections will be presented first. They are followed by the findings from the second part of the written reflections. Excerpts of data are used to illustrate and elaborate the findings.

\section{Results}

All the students seemed to be motivated in reflecting the relation between identity and art history. The data revealed no gender-based differences in terms of the length or complexity of the answers. Similarly, no significant differences were detectable between younger and older students' answers. Even though some students answered "no" to the questions "Is art history meaningful in terms of identity?", "Has your self-conception changed during art history studies?", and "Has your conception or understanding of the world changed during art history studies?", they nevertheless answered the open-ended questions, bringing out the contributions of art history to identity.

The presentation of the results is divided into three sections based on the questions posed to the participants: 1) the relation between identity and art history in general, 2) the contribution of art history studies to students' own selfconception, and 3) the contribution of art history studies to students' own understanding of the world. In each section, the results of the quantification of the three most frequently mentioned identity-related themes will be presented first. These are followed by an elaboration on the themes, accompanied by excerpts from the data.

\subsection{Relation between identity and art history}

The quantification showed that all the participants except for one experienced art history as meaningful in terms of identity (Table 2a, question 1). However, in the answers to question two, all the students raised issues that can be understood as contributions to identity work (Table $\mathbf{2 b}$, question 2 ). The most important contributions of art history in terms of identity were considered to be: 1) through art history, people can find new insights into themselves and the world in general (18 students), 2) reflecting on emotions and thoughts in relation 
to art history increases knowledge and awareness of the self (14 students), and 3) knowledge of art history increases self-confidence (10 students).

Table 2a. Question 1: Is art history meaningful in terms of identity?

\begin{tabular}{|l|l|}
\hline Answer & Number of students (total 24) \\
\hline Yes & 22 \\
\hline Yes and no & 1 \\
\hline No answer & 1 \\
\hline
\end{tabular}

Table 2b. Question 2: How can art history contribute to identity based on your thoughts and experiences?

\begin{tabular}{|l|l|}
\hline Answer & Number of students (total 24) \\
\hline $\begin{array}{l}\text { You can find new insights into yourself } \\
\text { and the world in general }\end{array}$ & 18 \\
\hline $\begin{array}{l}\text { Reflecting on emotions and thoughts in } \\
\text { relation to art and art history increases } \\
\text { self-knowledge }\end{array}$ & 14 \\
\hline $\begin{array}{l}\text { Knowledge of art history increases } \\
\text { self-confidence }\end{array}$ & 10 \\
\hline
\end{tabular}

The students participating in this research thought that art history can positively contribute to the development of identity. They experienced art history as able to guide people to see themselves and the world from a new perspective and, in doing so, to make them notice previously unknown aspects. In addition, the students thought that art history can increase self-knowledge, as well as knowledge about the world in general. It seemed the reflection on works of art in relation to students lived experiences contributed to a novel way of observing the world and themselves.

"The knowledge of art history develops students' insight into the world of art and helps them to understand it better. When you understand the world better, you also understand yourself and your actions better. (...) Knowledge of art history helps you to see where you come from. I think it helps you to understand and approve of yourself." (student 16)

"Knowledge of art history widens your world view and gives perspective to make sense of current issues and phenomena." (student 23)

Studying and exploring art and art history emerged as exploring oneself as well. Art historical knowledge appeared as a tool that students used when reflecting on their everyday experiences, as well as on their artistic work. It seemed to "give name" to their previously tacit intentions and experiences and helped them to become conscious of these intentions and experiences.

\footnotetext{
"As an art student, you can realize that you have created artworks that remind you of some art historical style. Through art historical knowledge, you can define and describe your works better - and maybe understand your motives that you weren't aware of when making the work." (student 10)
} 
Studying art history was also regarded as strengthening students' identity as art students. Art history was thought to deepen and diversify students' understanding of art made by other people, as well as by themselves. Students' reflections implicitly included an emancipatory tone, since art history was experienced as providing students with a new kind of insight into the world, art, and themselves, which was experienced as empowering.

"The knowledge of your field of study is important; it promotes your selfconception and increases self-assurance. Through art history, you can define yourself and your own role. Art history has given me courage to analyze works of art. I can use it as a resource in my artistic expression, as well." (student 11)

Students understood identity to be continually changing and in the process of constant reconstruction. It was experienced that art history can promote this process of self-exploration.

"Identity changes constantly in some direction. (...) The more you are involved with art history, the more you use art and art history to mirror yourself." (student 22)

All the students experienced art history as meaningful in terms of identity. The students considered art history as providing a novel kind of insight into themselves, as well as into the world around them. Consequently, art history emerged as self- and world-exploration, providing resources for identity work.

\subsection{Contribution of art history studies to the conception of the self}

Thirteen students experienced studying art history as contributing to their selfconception. In addition, three students answered "yes and no." Five students did not recognize any changes in their self-conception, two students answered "I don't know," and one student did not answer the question. Even though these eight students did not at first recognize any contributions of art history to their self-conception, or were hesitant as to whether there was any contribution (Table 3a, question 3), they mentioned such contributions in open-ended answers (Table 3b, question 4). Typically, their answers began "I don't know if art history has changed my self-conception, but I have realized that I (...)" (student 8), and then they mentioned topics related to identity, as listed in Table $2 \mathrm{~b}$. The most frequently mentioned contribution of art history to identity was related to the creation of artworks: sixteen students experienced art history as contributing to a deeper understanding of their own works of art, as well as increasing their self-confidence as art students. Eight students reported that their skills of self-reflection and observation in general had increased and become more analytical. The third most frequently mentioned aspect of identity was increased knowledge and appreciation of other cultures and one's own cultural roots (seven students). 
Table 3a. Question 3: Has your self-conception changed during art history studies?

\begin{tabular}{|l|l|}
\hline Answer & Number of students (total 24) \\
\hline Yes & 13 \\
\hline No & 5 \\
\hline Yes and no & 3 \\
\hline I don't know & 2 \\
\hline No answer & 1 \\
\hline
\end{tabular}

Table 3b. Question 4: If you feel your self-conception has changed, please specify how. Write about you experiences.

\begin{tabular}{|l|l|}
\hline Answer & Number of students (total 24) \\
\hline $\begin{array}{l}\text { Understanding of my own art has } \\
\text { deepened and self-assurance has } \\
\text { increased }\end{array}$ & 16 \\
\hline $\begin{array}{l}\text { Skills of self-reflection and analytical } \\
\text { observation have improved }\end{array}$ & 8 \\
\hline $\begin{array}{l}\text { Knowledge and appreciation of other } \\
\text { cultures and my own cultural roots } \\
\text { have increased }\end{array}$ & 7 \\
\hline
\end{tabular}

After reflecting on the relation between art history and identity at a more general level, the students were asked if art history had changed their conception of themselves somehow. All the students were able to identify novel aspects in their self-conception. When reflecting on the role of art history in terms of their own artistic expression, the students were of the opinion that art history had provided them with a novel kind of insight into art, which contributed to their self-confidence in making and analyzing works of art. The arts were experienced as an integral part of identity, and the students thought that art history had made an important contribution to this experience.

"Through art history, I have received more self-confidence in terms of life in general and in terms of my own works in particular. Through art and through making art, I define myself. It is such an important part of me and my identity." (student 9)

Change in the ways of thinking in general was characterized as increased knowledge about the world and art, contributing to a qualitative change in thinking. In addition, the students had found new interests when studying art history.

"Art history (...) has made me more broad-minded. Nowadays (...) if I don't like something, I start asking why I don't like it. (...) Analyzing works of art has contributed to this. For example, when we started to study abstract art, I didn't even regard it as art. But when we familiarized ourselves with the ideas and motives behind abstract art, I realized that my attitude was stupid." (student 12) 


\begin{abstract}
"Through art history studies, I noticed I was more interested in history than I had realized. I also understood how important history is in terms of developing as an art student and as a person in general. I have become more critical. I have still a lot to learn." (student 16)
\end{abstract}

For many students, the realization that art history not only discusses art and artists of past times, but also contemporary arts and the ways in which contemporary people perceive and interpret art based on their lived experiences, appeared to be important. It seemed to contribute to the experience that art history can be meaningful in terms of contemporary times, including students' thoughts, experiences, and actions. Art history was considered to provide tools for making sense of the present, as well.

"I am more interested in art history, because I have found that it also talks about us, contemporary people, and the issues of present times. It may help to understand them better. (...) I feel art history also positions me when I realize I am a part of this long continuum of history. It is somehow reassuring." (student 17)

Students also reflected on their relation to other cultures, as well as their own cultural roots. They were of the opinion that they had learned a lot about them and become more aware of them. In addition, interest in and appreciation of their culture had increased.

"I am more aware of my role and position in the world and in history. I also realize how remote a place Finland is. But I also realize that our country, culture, and people are specific. We can make a significant contribution to the art world, for instance, when we know our roots and appreciate them." (student 11)

The change in the students' self-conception was relatable to their increased selfassurance as art students and future artists. It seemed that the art historical knowledge and perspective provided them with a frame that helped them to locate themselves in the field of the arts. In addition, art history was found to be interesting because it also helped the students to understand the present, as well as to recognize and appreciate their cultural roots. Self-conception emerged as including not only one's own thoughts and actions, but also their relation to the wider culture.

\title{
6.3 Contribution of art history studies to the conception of the world
}

Twenty-two students wrote that art history had changed their conception of the world. Two students did not at first recognize any changes (Table 4a, question 5 ), but in the end they, too, identified changes in their relation to society (Table $4 \mathrm{~b}$, question 6). The most frequently mentioned aspect in terms of a changed conception of the world (16 students) was the fact that the students had begun to pay more attention to the relation between art and the environment, society, and/or culture. In addition, they reported that this had generated a new kind of interest in the environment, society, and/or culture in general. Eight students reported that their understanding and skills in analyzing the interconnectedness 
between art and society had developed. Finally, five students identified a desire to express their own opinions on social matters and to participate in social discussion through art.

Table 4a. Question 5: Has your conception or understanding of the world changed during art history studies?

\begin{tabular}{|l|l|}
\hline Answer & Number of students (total 24) \\
\hline Yes & 22 \\
\hline No & 2 \\
\hline
\end{tabular}

Table 4b. Question 6: How has studying art history changed your conception or understanding of the world? Write about your experiences and observations.

\begin{tabular}{|l|l|}
\hline Answer & Number of students (total 24) \\
\hline $\begin{array}{l}\text { More attention than before is paid to } \\
\text { the relation between art and } \\
\text { society/culture }\end{array}$ & 16 \\
\hline $\begin{array}{l}\text { Understanding of the } \\
\text { interconnectedness of art and } \\
\text { society/culture has deepened }\end{array}$ & 8 \\
\hline $\begin{array}{l}\text { Urge to promote important } \\
\text { issues/influence others through art has } \\
\text { increased }\end{array}$ & 5 \\
\hline
\end{tabular}

The change in the students' relation to the world around them was mainly characterized as a more active and close observation and interpretation of people, events, and phenomena in social interaction, the arts, and the media. It seemed the students had understood the interconnectedness of arts and societies or cultures more profoundly during their art history studies, which had translated into an increased interest in local and global social and environmental issues. They wanted to be more informed about social issues in order to be able to comment them in their own works of art.

"Nowadays I follow news in the media more than before. Because I have learned that the arts have always reflected their times and societies, I think it is important for me as an art student to know what is happening in the world." (student 5)

In addition to the increased interest in current affairs and their contribution to the arts in general, the students felt they had learned skills in noticing cultural and social influences in artworks. The skills in visual literacy, in terms of reflecting artworks in relation to their social and cultural contexts, were regarded as developing critical thinking.

"I don't know if it is only the contribution of art history, or of learning and growing as well, but I'm more curious and critical in relation to the surrounding world. I don't take things to be self-evident any more. Through art history, I have learned to observe art and the issues connected with it with new eyes." (student 22) 
The interconnectedness of arts and cultures or societies, as well as the realization that artworks do not neutrally mirror their times, motivated some students to speak out and promote important issues through artistic activity. The arts were understood as a means of influencing social matters, which seemed to foster the students' agency in terms of active participation in social discussion through art.

"I have become more interested in people's well-being and the course of the world. I want to make art that makes the world a better place and that makes people start to think more." (student 3)

"Art history has influenced the way I look at world. Until now I have been a spectator, but in the future, I want to be a story-teller who pays attention to important issues." (student 15)

The students thought that art history studies had increased their interest in social matters. The realization that arts and societies or cultures are mutually dependent motivated students not only to analyze societies and works of art more closely and critically, but also to use their own art as a means of social influence. In terms of identity, this seemed to foster the students' agency as art students and (future) artists.

\subsection{Summary of the results}

The students experienced that art history can guide people to see themselves and the world from a new perspective and, in doing so, reveal previously unknown aspects. Thus, studying and exploring art and art history emerged as exploring oneself and the world, as well. The knowledge of art history, arts, societies, and cultures broadened the students' world-view and increased their appreciation of other cultures, as well as their own cultural roots - as evidenced by students' reflections.

In addition, studying art history was regarded as strengthening the students' identity as art students. The students' reflections included emancipatory tones, since art history was experienced as providing the students with a new kind of insight into the world, art, and themselves, which was experienced as empowering. This resulted in a willingness to participate in social discussion and to influence social matters through art. In addition, it seemed that studying art history strengthened critical awareness of challenging social matters that had been taken for granted and providing alternative ways of seeing the world. It became evident that the students understood identity as a broad concept, including the awareness that cultural and social contexts contribute to people's sense of identity. Finally, identity was regarded as continually changing and in the process of constant reconstruction. It seemed that the students were curious about this fluid character of identity and welcomed the new nuances of identity as possibilities for new insights into themselves and the world at large. The following bullets summarize the key findings of the study.

- Art history guided students to see themselves from a new perspective

- Art history guided students to see the world from a new perspective 
- Art history broadened students' worldview

- Art history increased appreciation of other cultures

- Art history studies strengthened students' identity as art students

- Art history studies strengthened students' critical awareness

If there are more than 1 author and their details are different, the details of the second author must be placed below the first one. If the details are common, follow this format: othername1 surname1 and othername2 surname2. Sections may or may not be numbered. Thus, both Introduction and 1. Introduction are equally acceptable. All text must be justified except where the alignment is explicitly mentioned. The default line spacing is 11 units.

\section{Discussion}

All the students participating in the research were students of visual arts. Making art had been a hobby and an important part of their lives already before the studies in visual arts and art history. This background may partly explain the fact that the students experienced art history as important in terms of identity. None of the students had studied art history before, so it provided them with a novel insight into visual culture. In addition, the picture-based teaching method used in art history teaching, including a range of visual assignments, differed from the traditional methods of teaching art history, such as lectures and seminars. As typical for qualitative research in general, the results of this smallscale research cannot be generalized to other contexts in a straight-forward manner. Furthermore, both study groups of art history were relatively small: one of them included fourteen students and the other included ten students.

All the students were of the opinion that art history is meaningful in terms of identity work, in which identity is understood as persons' conceptions of themselves and the world around them. This result is in accordance with the findings of previous research concerning the relation of identity and the arts and art history (Albertson, 2011; Bender, 2017; Kozinets, Gretzel \& Dinhopl, 2017). However, written reflections included in this study, clearly activated and motivated students to relate art history studies to their own personal experiences. Observing and analyzing works of art was simultaneously considered to be exploring oneself, as a result of which the students felt they had learned to perceive and understand themselves and the world around them in more profound and versatile ways. This result suggests that studying art history acquired a transformative dimension in terms of a novel kind of self-experience, as is typical of an aesthetic experience (see Brandstätter, 2008). Thus, studying art history emerged not only as a construction of the knowledge of art history, but also as a construction of the self (see Washabaugh, 2008).In their written reflections, students clearly positioned themselves in relation to art history, which seemed to contribute to their identity as art students.

The students felt that through studying art history, they constructed their conceptions of the arts and art history, as well as of the world at large. Observing and reflecting on works of art, as well as art historical topics from 
different perspectives, seemed to concretize for students how the perspectives of observation contribute to art historical knowledge. Consequently, studying art history, and reflecting on the matters of identity related to it, seemed to contribute to an understanding of knowledge and reality as socially constructed, which is reminiscent of the conceptualization of social constructionism (Berger \& Luckmann, 1991; Burr, 2015). For some students, this realization resulted in an activated relationship with the surrounding world, motivating them to voice their opinions on social matters (e.g. people's well-being and ethnic diversity) and use the arts as a means of promoting important ideas and issues. These kinds of experiences and determination refer to the development of metacognitive skills characterized by people's ability to analyze their knowledge and skills, as well as their ability to use the outcomes of such analytical thinking to direct their actions in meaningful ways (Coskun, 2018; Perry, Lundie \& Golder, 2018). In addition, the experience is reminiscent of cultural empowerment, in which people use their perceptions of the cultural context to create activities and products in order to assert their views, which are considered as important (Shifrin, 2008). Bauman (2000) regards the will and ability to conduct action in the direction of one's intentions and wishes as central characteristics of emancipation.

The important role that visual material plays in the construction of identities is emphasized in visual culture studies and media studies (Elkins, 2008; Sturken \& Cartwright, 2017). Saastamoinen (2006b) states that identities are constructed through relations expressing diversity. Materializing social ideas, conditions, motivations, and aspirations from various periods of time, as well as from various cultures, works of art seemed to act as the embodiment of the diversity that activated reflections on identity among art history students. As this study shows, works of art, as well as art history, acted as a cultural mirror (Martikainen, 2011) through which students encountered otherness in terms of unfamiliar people, habits, and scenes. This emerged as a fruitful basis for reflecting on identity.

Art history seemed to provide the students with a significant arena for reflecting on their identity. The conception to identity used in this research is based social constructionism (Burr, 2015). However, this approach to identity was not discussed with the students in advance. Interestingly, the students' answers to the first two questions in the first stage, in which they reflected on the relation of identity and art history in general, revealed that they understood both selfconception and conception of the world to be included in the concept of identity. Thus, the conception of identity that emerged from the data can be associated with constructionist conceptions of identity in terms of evolving through experience and constructed in relation to social contexts and situations (Burr, 2015; Cameron, 2004; LaPointe, 2011; Stets \& Burke, 2000). In addition, the data reveal aspects of postmodern identity characterized by several identities activated by various social contexts (Bauman, 2000, 2001).

Pedagogical actions construct identities (Danforth \& Smith, 2005). For this reason, pedagogical solutions must be sustainable and promote students' 
development toward active citizenship. One may ask whether teaching methods that contribute to students' conceptions of identity as socially constructed plural identities are ethical, sustainable, and justified, since they are argued to problematize people's relation to their environment and to themselves (see Parfit, 2017; Weeks, 1990). Bauman (2000) regards it as important that education in modern societies promotes identity work that provides students with the possibility to reflect on themselves in relation to their social and cultural contexts. The mutuality of identities and contexts is seen as a means of promoting multicultural encounters, as well as of providing individuals with a means of appreciating themselves and others despite differences in opinions and worldviews (Bauman, 2000). According to Hall (1994), the conception of identity as a finished and coherent entity is nothing more than a fantasy. However, even though contemporary identities may be fragmented, temporary, and contradictory, this does not downplay the role of identity work. Quite the contrary, contemporary times presuppose that people can navigate between various identities and understand their contextual nature (Gündüz, 2017; Smaldino, 2017; Waters \& Fivush, 2015). Based on this research, it seems to be important that education can help and support the construction of identities (see also Von Korff \& Grotevant, 2011).

Bauman (2000) argues that history can positively contribute to identity work, providing people with points of reflection that enable them to learn about themselves and know themselves better. Similarly, Zijlmans (2008) regards art history as meaningful in constructing the identities of people and communities. In this process, the time-related perspective that history offers plays a significant role, since it provides people with a means of locating themselves in a larger cultural frame (see Martikainen, 2017a; Bauman, 2000). Bauman (2001, 2008) argues that the perspective that history offers is important in terms of understanding the present. For its part, the present offers a perspective for reflecting on the past, contributing to its critical understanding (Martikainen, 2017a). Modern people are often considered to be distanced, or even alienated from tradition (Saastamoinen, 2006b). Based on this research, the revitalization of this relation may have fruitful outcomes in terms of identity.

\section{Conclusion}

Studying art history using the methods of observing works of art and making art history-related visual products appeared to be fruitful in terms of reflecting on identity. In the written reflections based on these methods, the students seemed to set themselves in dialogue with artists, people, objects, events, and phenomena from past and other cultures. The dialogical perspective of art history seemed to promote the students' refection on themselves in relation to "others". It seemed that this kind of dialogical approach revealed identity as relational, situational, and socially constructed. In addition, the various facets of art history seemed to conceptualize identity as dynamic and in the process of reconstruction. The fact that art history changed the students' previous conceptions of cultures was considered to be a valuable contribution of art history studies. The possibility, provided by art history studies, to learn to know 
and get in touch with new layers of oneself emerged as highly rewarding. Based on these results, art history in general, and picture-based methods of teaching and learning art history in particular, may promote students' self-awareness and cultural appreciation as parts of their identity work.

In the future, it would be interesting to study the relationship between art history studies and identity at other levels of education as well, and among students majoring on other subjects than visual culture studies. Similarly, it would be interesting to study the relationship between history studies and student identity not only in Finland but also in other countries.

\section{References}

Adams, M. (2003). The reflexive self and culture: A critique. British Journal of Sociology, 54(2), 221-238. https//doi.org/10.1080/0007131032000080212

Albertson, R. A. (2011). Art and identity: The high school artist. MA thesis, University of Iowa.Retrieved from: https://ir.uiowa.edu/etd/2667

Ankersmit, F. (2003). Rococo as the dissipation of boredom. In C. Farago \& R. Zwijnenberg (Eds.), Compelling visuality: The work of art history in and out of history (pp. 132-155). Minneapolis, London: The University of Minnesota Press.

Bamberg, M. (2011). Who am I? Narration and its contribution to self and identity. Theory \& Psychology, 21(1), 3-24. https://doi.org/10.1177/0959354309355852

Bamberg, M., De Fina, A., \& Schiffrin, D. (2011). Discourse and identity construction. In S. J. Schwartz, K. Luycks \& V. L. Vignoles (Eds.), Handbook of identity theory and research (pp. 177-199). Berlin, Germany: Springer. https://doi.org/10.1007/9781-4419-7988-9_8

Bauman, Z. (2000). Liquid modernity. Malden, MA: Polity Press.

Bauman, Z. (2001). Identity in the globalising world. Social Anthropology, 9(2), 121-129. https://doi.org/10.1017/S096402820100009X

Bauman, Z., \& Haugaard, M. (2008). Liquid modernity and power: A dialogue with Zygmunt Bauman. Journal of Power, 1(2), 111-130. https://doi.org/10.1080/17540290802227536

Beech, N., MacIntosh, R., \& McInnes, P. (2008). Identity work: Processes and dynamics of identity formation. International Journal of Public Administration, 31(9), 958-970. https:// doi.org/10.1080/01900690801920411

Bender, G. H. (2017). Why world art is urgent now: Rethinking the introductory survey in a seminar format. Art History Pedagogy \& Practice, 2(2). Retrieved from: https://academicworks.cuny.edu/ahpp/vol2/iss2/2

Benwell, B., \& Stokoe, E. (2006). Discourse and identity. Edinburgh: Edinburgh University Press.

Berger, P. L., \& Luckmann, T. (1991). The social construction of reality. A treatise in the sociology of knowledge. London: Penguin.

Bilsker, D. (1992). An existentialist account of identity formation. Journal of Adolescence, $15,177-192$.

Blocker, G. H. (2004). Varieties of multicultural art education: Some policy issues. In E. W. Eisner \& M. D. Day (Eds.), Handbook of research and policy in art education (pp. 187-199). Mahwah, New Jersey: Lawrence Erlbaum.

Brandstätter, U. (2008). Grundfragen der Ästhetik: Bild - Musik - Sprache - Körper. [Basic questions of aesthetics: Image - music - language - body.] Köln, Weimar, Wien: Böhlau. 
Brown, A. D. (2015). Identities and identity work in organizations. International Journal of Management Reviews, 17(1), 20-40. https://doi.org/10.1111/ijmr.12035

Burr, V. (2015). Social constructionism. London: Routledge.

Cameron, J. E. (2004). A three-factor model of social identity. Self and Identity, 3(3), 239262. https://doi.org/10.1080/13576500444000047

Chere-Masopha, J. (2018). Personal landscapes of teacher professional identities versus digital technology adoption and integration in Lesotho schools. International Journal of Learning, Teaching and Educational Research, 17(3), 28-42. https://doi.org/10.26803/ijlter.17.3.3

Coskun, Y. (2018). A study on metacognitive thinking skills of university students. Journal of Education and Training Studies, 6(3), 38-46. Retrieved from: http://jets.redfame.com

Daher, M., Carré, D., Jaramillo, A., Olivares, H., \& Tomicic, A. (2017). Experience and meaning in qualitative research: A conceptual review and a methodological device proposal. Forum: Qualitative Social Research 18(3). https:// doi.org/10.17169/fgs-18.3.2696

Danforth, S., \& Smith, T. J. (2005). Engaging troubling students: A constructivist approach. Thousand Oaks, CA: Corwin Press.

Dyck, C. W. (2006). Empirical consciousness explained: Self-affection, (self-) consciousness and perception in the B deduction. Kantian Review, 11, 29-54.

Elkins, J. (2008). Introduction: The concept of visual literacy, and its limitations. In J. Elkins (Ed.), Visual Literacy (pp. 1-9). New York, London: Routledge.

Ericson, M. (2004). Interaction of teachers and curriculum. In E. W. Eisner \& M. D. Day (Eds.), Handbook of research and policy in art education (pp. 467-486). Mahwah, NJ: Lawrence Erlbaum.

Fuller, C. (2018). The essential self: Challenging and renegotiating gender identity through higher education in England. Gender and Education, 30(1), 92-104. https:// doi.org/10.1080/09540253.2016.1241380

Gardner, W. L., \& Garr-Schultz, A. (2018). Understanding our groups, understanding ourselves: The importance of collective identity clarity and collective coherence to the self. In J. Lodi-Smith \& K. DeMarree (Eds.), Self-concept clarity: Perspectives on assessment, research, and applications (pp. 125-143). Cham: Springer.

Gaudemard, L. (2018). Descartes's conception of mind through the prism of imagination: Cartesian substance dualism questions. Archiv für Geschichte der Philosophie (de Gruyter), 100(2), 146-171. https://doi.org/10.1515/agph-2018-2002

Giddens, A. (1992). The transformation of intimacy. Cambridge: Polity Press.

Gosine, K. (2002). Essentialism versus complexity: Conceptions of racial identity construction in educational scholarship. Canadian Journal of Education, 27(1), 81100.

Gündüz, U. (2017). The effect of social media on identity construction. Mediterranean Journal of Social Sciences, 8(5), 85-92. Retrieved from: http://creativecommons.org/licenses/by-nc-nd/3.0

Hall, S. (1994). Cultural identity and diaspora. In P. Williams \& L. Chrisman (Eds.), Colonial discourse and post-colonial theory: A reader (pp. 222-237). London: Harvester Wheatsheaf.

Hamilton, S., \& Hamilton, T. J. (2015). Pedagogical tools to explore Cartesian mind-body dualism in the classroom: Philosophical arguments and neuroscience illusions. Frontiers in Psychology, 11(6). https://doi.org/10.3389/fpsyg.2015.01155

Harris, J. (2001). The new art history. A critical introduction. London, New York: Routledge.

Kendell, E. (2009). Narrative as identity: Postmodernism, multiple ethnicities, and narrative practice approaches in social work. Journal of Ethnic and Cultural $\begin{array}{llll}\text { Diversity in Social Work, 18(3), 221-241. } & \text {. }\end{array}$ https://doi.org/10.1080/15313200903070973 
Knapik, M. (2006). The qualitative research interview: Participants' responsive participation in knowledge making. International Journal of Qualitative Methods, 5(3), 77-93. https://doi.org/10.1177/160940690600500308

Kozinets, R., Gretzel, U., \& Dinhopl, A. (2017). Self in art/self as art: Museum selfies as identity work. Frontiers in Psychology, 8 https:// doi.org/10.3389/fpsyg.2017.00731

Kraynak, J. (2007). Art history's present tense. In E. C. Mansfield (Ed.), Making art history: A changing discipline and its institutions (pp. 83-101). New York: Routledge.

Krieger, V. (2008). Einführung: Zeitgenossenschaft als Herausforderung für die Kunstgeschichte [Introduction: Contemporaneity as a challenge for art history]. In V. Krieger (Ed.), Kunstgeschichte \& Gegenwartskunst: vom Nutzen \& Nachteil der Zeitgenossenschaft [Art history and contemporary art: Advantages $\mathcal{E}$ disadvantages of contemporaneity] (pp. 5-25). Köln, Weimar, Wien: BöhlauVerlag.

Krippendorff, K. (2013). Content analysis. An introduction to its methodology. London: Sage.

Kuusela, P. (2006). Realismi ja sosiaalisen identiteetin episteeminen status. Modernista minäpsykologiasta postpositivistiseen realismiin [Realism and the status of epistemic social identity. From modern psychology of self to post positivistic realism]. In P. Rautio \& M. Saastamoinen (Eds.), Minuus ja identiteetti. Sosiaalipsykologinen ja sosiologinen näkökulma [Self and identity. A social psychological and sociological approach] (pp. 36-56). Tampere: Tampere University Press.

LaPointe, K. (2011). Moral struggles, subtle shifts. Narrative practices of identity work in career transitions. Aalto University School of Economics. Aalto University Publications Series, Doctoral Dissertations, 34/2011.

Larsen, G., \& Patterson, M. (2018). Consumer identity projects. In O. Kravets, P. Maclaran, S. Miles \& A. Venkatesh (Eds.), SAGE Handbook of consumer cultures (pp. 194-213). London: Sage.

Laulainen, S., \& Hujala, A. (2016). Material construction of care workers' identity. Nordic $\begin{array}{lllll}\text { Journal of Working Life Studies, } & \text { 6(S1), }\end{array}$ https:// doi.org/10.19154/njwls.v6i1.4883

Mansfield, E. C. (2007). Introduction: Making art history a profession. In E. C. Mansfield (Ed.), Making art history: A changing discipline and its institutions (pp. 1-9). New York: Routledge.

Martikainen, J. (2011). Käsitettävä taidehistoria. Kuvalähtöinen malli taidehistorian opetukseen kuvallisen ilmaisun ammatillisessa perustutkinnossa. [Grasping art history: A picturebased model for teaching art history in the vocational basic degree in visual arts.] Jyväskylä Studies in Humanities 156. Jyväskylä: Jyväskylä University Press.

Martikainen, J. (2017a). Making pictures, writing about pictures, discussing pictures and lecture-discussion as teaching methods in art history. Art History Pedagogy $\mathcal{E}$ Practice 2(1), 1-36. Retrieved from: https://academicworks.cuny.edu/ahpp/vol2/iss1/4

Martikainen, J. (2017b). Making pictures as a method of teaching art history. International Journal of Education $\mathcal{E}$ the Arts, 18(19), 1-25. Retrieved from: http://www.ijea.org/v18n19/

Leah, S., Mathews, C., Harrison, A., \& Chavous, T. (2019). Racial identity, racial domination, and classroom engagement outcomes among black girls and boys in predominanatly black and predominantly white school districts. American Educational Research Journal, 1-13. https://doi.org/10.3102/0002831218816955 (in press)

McLean, K. C. (2008). Stories of the young and the old: Personal continuity and narrative identity. Developmental Psychology, 44(1), 254-264. https://doi.org/10.1037/00121649.44.1.254 
Mead, G. H. (2015). Mind, self, and society. Edited by C. W. Morris. Chicago: University of Chicago Press.

Miller, A. L., Berlo, J. C., Wolf, B. J., \& Roberts, J. L. (2018). American encounters: Art, history, and cultural identity. Books and Monographs, 39. St. Louis, Missouri: Washington University Libraries. Retrieved from: https://openscholarship.wustl.edu/books/39

Moser, A., \& Korstens, I. (2018). Practical guidance to qualitative research. Part 3: Sampling, data collection and analysis. European Journal of General Practice, 24(1), 9-18. https://doi.org/10.1080/13814788.2017.1375091

Nawar, T. (2017). The Stoics on identity, identification, and peculiar qualities. Proceeding of the Boston Area Colloqium of Ancient Philosophy, 32(1), 113-159. https://doi.org/10.1163/22134417-00321P11

Neale, J., Miller, P., \& West, R. (2014). Reporting quantitative information in qualitative research: Guidance for authors and reviewers. Addiction, 109, 175-176. https://doi.org/10.1111/add.12408

Onorato, R. S., \& Turner, J. C. (2004). Fluidity of the self-concept: The shift from personal to social identity. European Journal of Social Psychology, 34(3), 257-278. https://doi.org/10.1002/ ejsp.195

Oyserman, D., Elmore, K., \& Smith, G. (2012). Self, self-concept, and identity. In M. R. Leary \& J. P. Tangney (Eds.), Handbook of self and identity (pp. 69-104). New York, London: The Guilford Press.

Parfit, D. (2017). Future people, the non-identity problem, and person-affecting principles. Philosophy and Public Affairs, 45(2), 118-157. https://doi.org/10.1111/papa.12088

Perry, J., Lundie, D., \& Golder, G. (2018). Metacognition in schools: What does the literature suggest about the effectiveness of teaching metacognition in schools? Educational Review, 1-18. https://doi.org/10.1080/00131911.2018.1441127

Pistioli, E. (2018). The self-concept in specific areas of students attending multigrade and single grade elementary schools. Comparative approach. International Journal of Learning, Teaching and Educational Research, 17(12), 116-134. https://doi.org/10.26803/ijlter.17.12.7

Pooke, G., \& Newall, D. (2008). Art history: The basics. London, New York: Routledge.

Rautio, P. (2006). Historiallista johdattelua minä- ja identiteettitutkimukseen [Historical introduction to the research on self and identity]. In P. Rautio \& M. Saastamoinen (Eds.), Minuus ja identiteetti. Sosiaalipsykologinen ja sosiologinen näkökulma [Self and identity. A social psychological and sociological approach] (pp. 1122). Tampere: Tampere University Press.

Rautio, P., \& Saastamoinen, M. (2006). Esipuhe [Foreword]. In P. Rautio \& M. Saastamoinen (Eds.), Minuus ja identiteetti. Sosiaalipsykologinen ja sosiologinen näkökulma [Self and identity. A social psychological and sociological approach] (pp. 910). Tampere: Tampere University Press.

Riechman, B. (2016). Who am I? Where am I going? And which path should I choose? Developing the personal and professional identity of student-teachers. International Journal of Learning, Teaching and Educational Research, 15(9), 17-83. https:// www.ijlter.org/index.php/ijlter/article/view/756/pdf

Ruelle, O., \& Peverelli, P. (2017). The discursive construction of identity through interaction on social media in a Chinese NGO. Chinese Journal of Communication, 10(1), 12-37. https://doi.org/10.1080/17544750.2016.1217899

Ryazanov, A. A., \& Christenfelf, N. J. S. (2017). The strategic value of essentialism. Social and Personality Psychology Compass, 12(1), 1-15. https://doi.org/10.1111/spc3.12370

Saastamoinen, M. (2006a). Yksilö, riskitietoisuus ja psykokulttuuri [Individual, risk awareness, and psycho culture]. In P. Rautio \& M. Saastamoinen (Eds.), Minuus 
ja identiteetti. Sosiaalipsykologinen ja sosiologinen näkökulma [Self and identity. A social psychological and sociological approach] (pp. 138-169). Tampere: Tampere University Press.

Saastamoinen, M. (2006b). Minuus ja identiteetti tutkimuksen haasteina [Self and identity as challenges for research]. In P. Rautio \& M. Saastamoinen (Eds.), Minuus ja identiteetti. Sosiaalipsykologinen ja sosiologinen näkökulma [Self and identity. A social psychological and sociological approach] (pp. 170-180). Tampere: Tampere University Press.

Sabol, R. (2000). Studying art history through multicultural education looking-glass. Art Education, 53(3), 12-17.

Saji, M. (2009). Three aspects of the self-opacity of the empirical subject in Kant. $\begin{array}{lllll}\text { Philosophy } \mathcal{E} \quad \text { Social } & \text { Criticism, 35(3), 315-337. }\end{array}$ https://doi.org/10.1177/0191453708100233

Shifrin, S. (2008). Visual literacy in North American secondary schools. In J. Elkins (Ed.), Visual Literacy (pp. 105-128). New York, London: Routledge.

Smaldino, P. E. (2017). Social identity and cooperation in cultural evolution. Behavioural Processes, 1-9. https:// doi.org/10.1016/j.beproc.2017.11.013

Stets, J. E., \& Burke, P. J. (2000). Identity theory and social identity theory. Social Psychology Quarterly, 63(3), 224-237. https://doi.org/10.2307/2695870

Sturken, M., \& Cartwright, L. (2017). Practices of looking: An introduction to the visual culture. New York, Oxford: Oxford University Press.

Tajfel, H., \& Turner, J. C. (2004). The social identity theory of intergroup behavior. In J. T. Jost \& J. Sidanius (Eds.), Key readings in social psychology. Political psychology: Key readings (pp. 276-293). New York: Psychology Press.

Van Damme, W. (2008). Introducing world art studies. In K. Zijlmans \& W. Van Damme (Eds.), World art studies: Exploring concepts and approaches (pp. 23-61). Amsterdam: Valiz.

Van Mechelen, M., \& Zijlmans, K. (2012). Art history in the Netherlands: The past and present of the discipline. In M. Rampley, T. Lenain, H. Locher, A. Pinotti, C. Schoell-Glass, K. Zijlmans \& R. Zwijnenberg (Eds.), Art history and visual studies in Europe (pp. 407-420). Brill's Studies on Art, Art History, and Intellectual History, 212(4). https://doi.org/10.1163/9789004231702_027

Von Korff, L., \& Grotevant, H. D. (2011). Contact in adoption and adoptive identity formation: The mediating role of family conversation. Journal of Family Psychology, 25(3), 393-401. https://doi.org/10.1037/a0023388

Washabaugh, W. (2008). Philosophical bases for visual multiculturalism at the college level. In J. Elkins (Ed.), Visual literacy (pp. 129-144). New York, London: Routledge.

Waterman, A. S. (2014). Identity and meaning: Contrast of existentialist and essentialist perspectives. International Journal of Existential Psychology \& Psychotherapy, 5(1), $33-44$.

Retrieved from: http://journal.existentialpsychology.org/index.php/ExPsy/article/view/200

Waters, T. E. A., \& Fivush, R. (2015). Relations between narrative coherence, identity, and psychological well-being in emerging adulthood. Journal of Personality, 83(4), 441-451. https://doi.org/10.1111/jopy.12120

Weeks, J. (1990). The value of difference. In J. Rutherford (Ed.), Identity: Community, culture, difference (pp. 88-100). London: Lawrence \& Wishart.

Zhao, S. (2014). Self as an emic object: A re-reading of William James on self. Theory and Psychology 24(2), 199-216. https:/ / doi.org/10.1177/0959354314527181

Zijlmans, K. (2008). The discourse on contemporary art and the globalization of the art system. In K. Zijlmans \& W. Van Damme (Eds.), World art studies: Exploring concepts and approaches (pp. 135-150). Amsterdam: Valiz. 
Yeo, H., Mendenhall, R., Harwood, S., \& Huntt, M. (2019). Asian international student and Asian American student: Mistaken identity and racial microaggressions. Journal of International Students, 9(1), 39-65 https://doi.org/10.32674/jis.v9i1.278 